\title{
LEAD EXPOSURE ASSESSMENT BETWEEN TWO LEAD WORKER GROUPS IN EL-BEIDA, LIBYA
}

\author{
Nusieba A Mohammed Ibrahim, Yahya Saber E Mansour \\ Department of Pharmacology and Toxicology \\ Faculty of Pharmacy \\ Omar Al-Mukhtar University, El-beida, Libya
}

\begin{abstract}
Objective: The main goal of this current research study was to determine the blood lead levels in two lead worker groups in El-beida city, Libya.

Materials and Methods: This study was carried out on males working in radiators repairing $(25$ workers) and batteries repairing ( 25 workers), compared with the control group ( 30 healthy males).

Results: Blood lead levels significantly increased in the radiators and batteries repairing worker groups $(p<0.01)$. A significant correlation was found between the duration of exposure and the blood lead levels of both groups, while there was an insignificant correlation between the age and the blood lead levels.

Conclusion: Blood lead levels of the radiators and batteries repairing worker groups were elevated. Blood lead levels correlated with the duration of lead exposure in radiators and batteries repairing workers, but not with their ages.
\end{abstract}

Keywords: Lead ( $\mathbf{P b})$, lead exposure, blood lead level, radiators and batteries repairing workers, El-beida, Libya

\section{INTRODUCTION}

Lead is a highly toxic metal that has been used by humans for over 2000 years and is one of the most poisonous metals known due to its wide-ranging effects on multiple body systems and processes that are necessary for normal function (Pattee et al., 2003). The renal, gastrointestinal, reproductive, central nervous and peripheral nervous systems, and the biosynthesis of heme are all adversely affected by lead (Verity, 1997). The lead absorption by lungs depends on several factors in addition to concentration, these include: i) Volume of air inspired per day, whether the lead is in particle or vapor form, and, ii) Size distribution of lead-containing particles. Only a very minor fraction of particles over $0.5 \mu \mathrm{m}$ in maximal external diameter are retained in the lung but are cleared from the respiratory tract and swallowed. The gastrointestinal absorption of lead is influenced by a large number of factors of which age and nutrition are of particular importance (Matte et al., 2000).
Lead is heavily used in industry including batteries, radiators, additives to gasoline, paints, explosives, pesticides, cosmetics, radiation shields, crystal glass, among others (Carolyn, 1997). However, due to its highly toxic effects, its uses in the industry have been highly limited in recent years. Several diseases and syndromes were attributed to lead exposure. The nervous system is the most affected, expressed mostly as sensory deficits and encephalopathy (Goyer, 2001). Anemia is also one of the common symptoms (Gossel, 1994). Moreover, lead influences the kidney by the development of hyperuricemia (Thomas et al., 2009), and above 40-50 $\mu \mathrm{g} / \mathrm{dl}$ causes testicular atrophy and hypospermia (lower fertility in men) as well as a miscarriage in a pregnant woman. One of the most identified health problems of lead is the deterioration in the bone strength, where $\mathrm{Pb}^{+2}$ may replace $\mathrm{Ca}^{+2}$ in the bone mineral phases and causes osteoporosis (James et al., 2010). Lead may cause mental retardation in children when exposed to more than $25 \mu \mathrm{g} / \mathrm{dl}$ (Richard, 2012). Up to 50\% of inhaled inorganic lead may be absorbed in the lungs. Adults take up $10-15 \%$ of lead in food, whereas children may absorb up to $50 \%$ via the gastrointestinal tract (GIT). Lead in the blood is bound to erythrocytes (red blood cells), and elimination is slow and principally via urine. Lead is accumulated in the skeleton (95\%) and is slowly released from this body compartment. The half-life $\left(\mathrm{t}_{1 / 2}\right)$ of lead in blood is about one month, and 20- 30 years in the skeleton (WHO, 1995). This study aimed to evaluate the blood lead levels in radiators and batteries repairing workers in El-beida city, Libya to assess the effects of environmental contamination on the levels of lead in the body fluids.

\section{MATERIALS \& METHODS}

The present study was conducted on workers from several workplaces where exposed to materials containing lead. The study was done between 2018-2019 in El-beida city, Libya. 


\section{International Journal of Engineering Applied Sciences and Technology, 2019 \\ Vol. 4, Issue 1, ISSN No. 2455-2143, Pages 24-27 \\ Published Online May 2019 in IJEAST (http://www.ijeast.com)}

Written agreement consents of each worker were obtained. Subjects were categorized into three groups, as follows:

A. Male Control Group: This group consisted of 30 apparently healthy male volunteers, their ages ranged between 18-55 years (mean \pm SD: $31 \pm 11.84$ ), who were not exposed to lead.

B. Radiators Repairing Worker Group: This group included 25 individuals, their ages ranged between 22-54 years (mean \pm SD: $34 \pm 10.59$ ), who were working in radiators repairing in the industrial area, and exposed to lead by inhalation and dermal contact during repairing. The duration of exposure ranged between 2-13 years (mean \pm SD: 8.0 $\pm 2.95)$.

C. Batteries Repairing Worker Group: This group also comprised of 25 individuals, their ages ranged between 17-52 years (mean \pm SD: $29 \pm 10.44$ ), who were working in lead-acid battery repairing shops. The duration of exposure ranged between 3-14 years (mean \pm SD: $8.8 \pm 2.76$ ).

Blood lead levels were determined by "LeadCare II-Blood Lead Test System" (Figure 1). This test is considered to be appropriate for field studies due to its cost-effective, easy-toapply, portable features, and reliable method (Pineau et al., 2002). Samples were collected by using disposable injectors. $50 \mu \mathrm{l}$ of blood samples were drawn from each worker by using capillary tubes and then transferred into vacuum blood tubes containing ethylenediaminetetraacetic acid (EDTA). The samples were mixed by gently rocking the tubes. The tubes were left to stand upright for a minute. The prepared samples were deposited onto electrode strips and then inserted into the analyzer. Within three minutes, the results appeared on the screen in $\mu \mathrm{g} / \mathrm{dl}$. The results were analyzed statistically by using the unpaired student's t-test to compare blood lead levels between worker groups and control group. The correlation coefficient ( $r$ ) was used to determine the relationship between the blood lead levels and the ages or duration of exposure between worker groups.

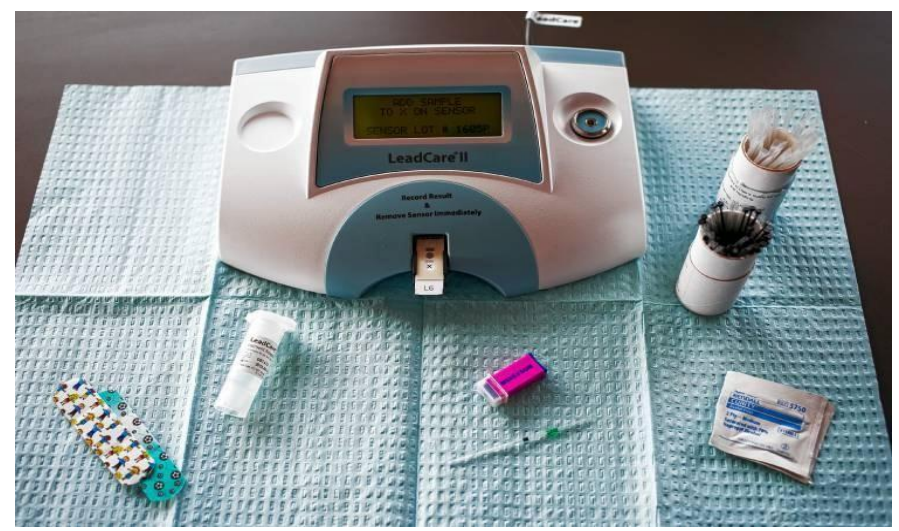

Fig. 1. LeadCare II-Blood Lead Analyzer.

\section{RESULTS}

Blood lead levels increased significantly in the radiators repairing $(22.7 \pm 6.69, \quad p<0.01)$ and batteries repairing
(17.4 $\pm 5.81, p<0.01)$ workers as compared with the control group (8.3 \pm 1.34$)$. The mean blood lead levels of the radiators and batteries repairing worker groups were relatively higher than the mean blood lead levels of the control group. Table 1 shows the results mentioned above.

Table-1 Blood lead levels (mean \pm S.D., range) of the radiators and batteries repairing worker groups, and the control group.

\begin{tabular}{|l|c|c|c|}
\hline Parameter & $\begin{array}{c}\text { Control Group } \\
(\mathrm{n}=30)\end{array}$ & $\begin{array}{c}\text { Radiator Group } \\
(\mathrm{n}=25)\end{array}$ & $\begin{array}{c}\text { Battery Group } \\
(\mathrm{n}=25)\end{array}$ \\
\hline $\mathrm{Pb}(\mu \mathrm{g} / \mathrm{dl})$ & $\begin{array}{c}8.3 \pm 1.34 \\
(5.5-13.0)\end{array}$ & $\begin{array}{c}22.7 \pm 6.69^{* *} \\
(9.4-34.9)\end{array}$ & $\begin{array}{c}17.4 \pm 5.81^{* *} \\
(7.7-30.9)\end{array}$ \\
& & & \\
& & & \\
${ }^{* *} p<0.01$ &
\end{tabular}

Figures 2 and 3 below show the significant correlation between the duration of exposure and the blood lead levels in radiators repairing $(p<0.01)$ and batteries repairing $(p<0.01)$ worker groups. While, there was a non-significant correlation between the age and the blood lead levels in the worker groups and the control group.

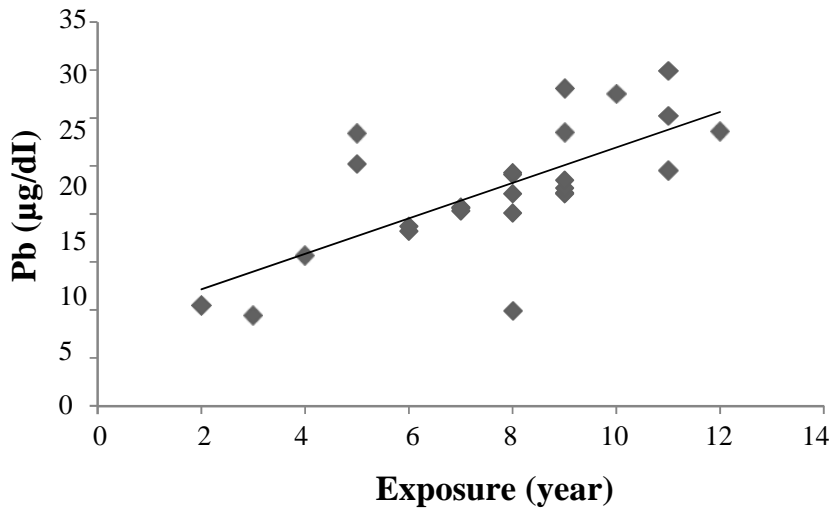

Fig. 2. Correlation coefficient (r) between the blood lead levels $(\mu \mathrm{g} / \mathrm{dI})$ and the duration of exposure (year) in radiators repairing worker group. 


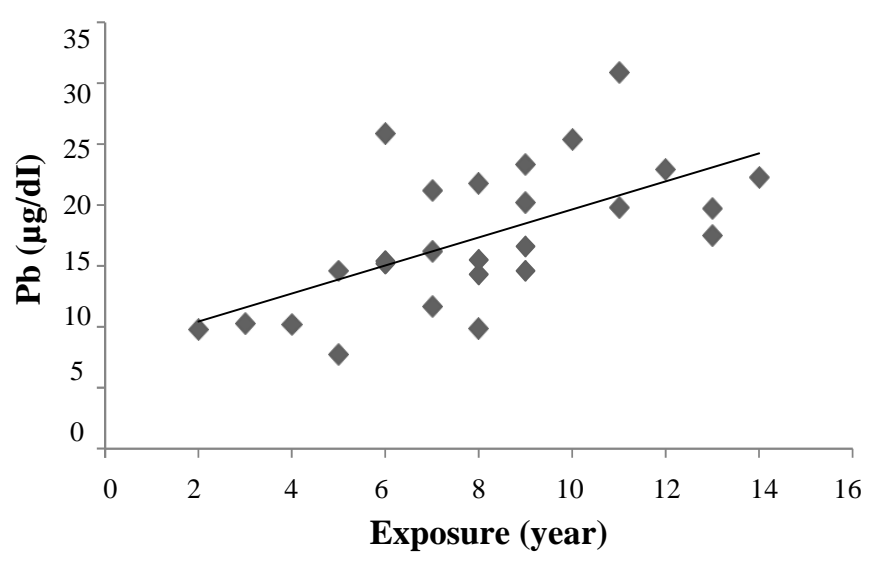

Fig. 3. Correlation coefficient (r) between the blood lead levels $(\mu \mathrm{g} / \mathrm{dI})$ and the duration of exposure (year) in batteries repairing worker group.

\section{DISCUSSION}

In general, the standard analysis of blood lead levels performed in laboratories around the world remains the most useful index of recent exposure (Kim et al., 2013). The US centers for disease control and prevention intervention level reported a higher blood lead levels if it is $\geq 10 \mu \mathrm{g} / \mathrm{dl}$ (WHO, 1995), and considered a cause for public health concern (Williams et al., 1998). This study documented occupational lead contamination from elevated lead blood levels in El-beida city between two worker groups in workplaces with materials containing lead. The significant difference between the blood lead levels in the control group, radiators, and batteries repairing worker groups leaves little doubts that regular exposure to lead during their work is associated with increased blood lead levels. This gives us that these workers exposed to lead during their work by inhalation, dermal contact (without using gloves), and ingestion from their contaminated hands. Similar was reported by many workers (Williams et al., 1998, Hodgkins et al., 1993, Fletcher et al., 1999, Tozun et al., 2009, Ahmed et al., 2008, Lai et al., 1997 and Hwang et al., 2000). A significant correlation was found between the blood lead levels and the duration of exposure in radiators and batteries repairing workers. These results are consistent with other studies (Matte et al., 2000, Mehdi et al., 2009 and Al-Khalidy et al., 2012). All working groups showed a non-significant correlation between ages and blood lead levels, as the individuals who included in this study, were adults, not children or elderly.

\section{CONCLUSION}

In conclusion, blood lead levels were elevated in both worker groups. Blood lead levels correlated with the duration of lead exposure in radiators and batteries workers, but not with their ages.

\section{CONFLICTS OF INTEREST}

We hereby declare that there are no conflicts of interest regarding the publication of this research study.

\section{ACKNOWLEDGMENT}

We would like to express our appreciation and thanks to all the participants in this research study. We would also like to thank the entire staff at Ras-Lanuf Medical Laboratory for their co-operation and helping us in the laboratory working. Finally, we appreciate everyone who supports us.

\section{ETHICS}

All participants provided written permission and consent before collecting data to conduct this research study.

\section{REFERENCES}

[1] Pattee, O.H. and Pain, D.J. (2003). Lead in the Environment. Chapter 15. In Hoffman, D.J., Rattner, B.A. Burton JrGA, Cairns JrJ (eds). Handbook of Ecotoxicology. Lewis Publ Boca Raton. (pp. 373-408).

[2] Verity, M.A. (1997). Toxic Disorders. In Graham, D.I., Lantos, P.L. Greenfield's Neuropathology 6th eds. Arnold London. (Vo. 1, pp. 755-811).

[3] Matte, T.D., Figueroa, J.P., Ostrowski, S., et al. (2000). Lead Poisoning Among Household Members Exposed to Lead- Acid Battery Repair Shops in Kingston. Inter J Epidem. (Vo. 18, No. 4, pp. 874-81).

[4] Carolyn, K. (1997). Lead Contamination in our Environment. Yale-New Haven Institute. (Vo. 1, pp. 5-18).

[5] Goyer, R. (2001). Toxic and Essential Metal Interactions. Annu Rev Nutr. (Vo. 17, pp. 37-50).

[6] Gossel, T.H. and Bricker, J. (1994). Principles of Clinical Toxicology 3rd eds. New York. (pp. 197).

[7] Thomas, E., Andreoli, M.D., Charles, E. and Carpenter, M.D. (2009). Cecil Essentials of Medicine 6th eds. (pp. 458).

[8] James, R., Randy, N. and Leonare, N. (2010). The Association Between Environmental Lead Exposure and Bone Density. Environ Health Perespec. (Vo. 12, pp. 1200-3).

[9] Richard, L.D. (2012). Very Low Lead Linked with IQ Deficits. Ace Natio Engl J. (Vo. 210, pp. 520-31).

[10] WHO (World Health Organization). Lead Environmental Health Criteria (1995). Geneva. (Vo. 165). 
[11] Pineau, A., Fauconneau, B., Rafael, M., et al. (2002). Determination of Lead in Whole Blood: Comparisons of the LeadCare Blood Lead Testing System with Zeeman Longitudinal Electrothermal AAS. J Trace Elem Med Biol. (Vo. 2, pp.113-17)

[12] Kim, H.S., Lee, S.S., Hwangbo, Y., et al. (2013). CrossSectional Study of Blood Lead Effects on Iron Status in Korean Lead Workers. Nutrition. (Vo. 19, No. 7-8, pp. 57176).

[13] Williams, G., Hall, L. and Addae, J. (1998). Increase in Hair Lead but not Blood Lead Content of OccupationallyExposed Workers. Environ Geochem Health. (Vo. 20, pp. 239-43).

[14] Hodgkins, D.G., Robins, T.G. and Hinkamp, D.L. (1993). A Longitudinal Study of the Relation of Lead in Blood to Lead in Air Concentrations Among Battery Workers. Br J Ind Med. (Vo. 49, pp. 241-8).

[15] Fletcher, A.M., Gelberg, K.H. and Marshall, E.G. (1999). Reasons for Testing and Exposure Sources Among Women of Childbearing Age with Moderate Blood Lead Levels. J Comm Health. (Vo. 24, No. 3, pp. 215-27).

[16] Tozun, M., Unsal, A. and Birmagul, B. (2009). The Lead Exposed Among Lead Workers: An Epidemiological Study from West Turkey. Iranian J Publ Health. (Vo. 38, No. 2, pp. 65-78).

[17] Ahmed, K., Ayana, G. and Engidawork, E. (2008). Lead Exposure Study Works in Lead Acid Battery Repair Units of Transport Service Enterprises Addis Ababa, Ethiopia, a CrossSectional Study. J Occup Med Toxi. (Vo. 3, No. 30, pp. 1-8).

[18] Lai, J.S., Wu, T.N. and Liou, S.H., et al. (1997). A Study of the Relationship Between Ambient Lead and Blood Lead Among Lead Battery Workers. Inter Arch Occup Environ Health. (Vo. 69, No. 4, pp. 295-300).

[19] Hwang, Y.H., Chao, K.Y., Chang, C.W., et al. (2000). Lead as an Alternative Measure for Lead Exposure Assessment of Lead Battery Assembly Workers. A I H A J. (Vo. 61, No. 6, pp. 825-31).

[20] Mehdi, J.K., Al-Imarah, F.D.M. and Al-Suhail, A.A. (2009). Levels of Some Trace Metals and Related Enzymes in Workers at Storage-Battery Factories in Iraq. Eastern Med Health J. (Vo. 6, No. 1, pp. 76-8).

[21] Al-Khalidy, K.S.H., Chabuk, A.J.A.K. and Kadhim, M.M.A. (2012). Measurement of Lead Pollution in the Air of Babylon Governorate/Iraq during Year 2010. World Acad Sci Eng Tech. (Vo. 62, pp. 826-9). 